\title{
Peru 2016: Continuity and Change in an Electoral Year
}

\author{
Perú 2016: continuidad y cambio en un año electoral
}

\section{STEPHANIE MCNULTY*}

Franklin and Marshall College, USA

\begin{abstract}
As an electoral year, 2016 confirmed the endurance of neoliberal economic models and democratic procedures in Peru. The election of Pedro Pablo Kuczynski, popularly known as PPK, points to another year of the "automatic pilot" mode from the right, with continued neoliberal programs in the context of weak and inefficient institutions. The national elections also illustrate the continued trajectory of peaceful, democratic transfers of power at the national level, evincing the Peruvian electorate's commitment to democratic procedures. Part of this commitment lies in a significant proportion of the population's persistent rejection of Keiko Fujimori as presidential candidate. At the same time, the quality of Peruvian democracy remains moderately low, due to a variety of factors including pervasive corruption, weak political parties, problematic state institutions, and inequality. This article outlines many of the patterns that persist despite the changes in leadership that were ushered in after the April and June national elections.
\end{abstract}

Key Words: Peru, Democracy, Governance

\section{RESUMEN}

Como un año electoral, 2016 demostró la resistencia de los modelos económicos neoliberales y los procedimientos democráticos en el Perú. La elección de Pedro Pablo Kuczynski, popularmente conocido como PPK, indica que Perú experimentó un año más del modo "piloto automático" de la derecha, con la continuación de programas neoliberales dentro de un contexto de instituciones débiles e ineficientes. Las elecciones nacionales ilustran también la trayectoria de transferencias pacíficas y democráticas de poder a nivel nacional, evidenciando el compromiso del electorado peruano con los procedimientos democráticos. Parte de este compromiso se basa en un persistente rechazo hacia Keiko Fujimori como candidata presidencial por parte de una significante proporción de la población. Al mismo tiempo, la calidad de la democracia peruana permanece moderadamente baja, debido a una variedad de factores, como la omnipresente corrupción, los débiles partidos políticos, las problemáticas instituciones estatales y los problemas de desigualdad y exclusión social. Este artículo esboza estos patrones que continúan persistiendo a pesar de los cambios en el liderazgo que se introdujeron después de las elecciones de abril y junio.

Palabras clave: Perú, democracia, gobernanza

\footnotetext{
The author would like to thank the editors of the Revista de Ciencia Politica for the opportunity to participate in this year's annual review as well as Dr. Maiah Jaskoski and an anonymous reviewer for their invaluable feedback. I would also like to thank my interviewees for their time and insight.
} 


\section{INTRODUCTION}

As an electoral year, observers might have expected 2016 to bring some major changes in Peru. However, apart from the change in national leadership, many political, social, and economic trends proved quite resilient. For example, 2016 confirmed the endurance of both neoliberal economic models and democratic procedures in Peru. In a hotly disputed presidential election, Pedro Pablo Kuczynski, popularly known as PPK, managed to win the second round, beating Keiko Fujimori by less than 1 percent of the vote. His win suggests that 2016 is best understood as a continuation of "automatic pilot" mode from the right, with continued neoliberal programs in the context of weak and inefficient institutions (see Dargent and Muñoz 2012).

The national elections also illustrate the continued trajectory of peaceful, democratic transfers of power at the national level, evincing the Peruvian electorate's commitment to democratic procedures. Part of this commitment lies in a significant proportion of the population's continued rejection of Keiko Fujimori-daughter of jailed ex-President Alberto Fujimori-as a presidential candidate. This trend should not be taken lightly in a country that has frequently swung back and forth between democracy and authoritarianism between 1919 and 2000. However, for the first time since Alberto Fujimori (1990-2000) resigned, Peru's commitment to democratic procedures was tested in 2016. Just weeks before the first round of the presidential elections, two popular candidates, Julio Guzmán and César Acuña, were barred from the race by the National Election Board (Jurado Nacional Electoral, JNE) on the grounds of inappropriate campaign procedures. It was the first time since 2000 that this government agency had played such an active role in determining the candidate pool (Sharkey 2016, 30 March).

Additional problematic aspects of continuity in Peruvian politics are the deeprooted problems of corruption, social exclusion, and institutional weaknesses that continue to prevent more robust strengthening of democratic governance. In 2016, corruption scandals plagued elected officials at the highest levels. Moreover, citizens continued to report high levels of skepticism about political institutions, including Congress and the judicial branch. Many social groups, including indigenous communities and Afro-Peruvians, continue to face ongoing discrimination and exclusion.

This article first reviews the political, economic, and social trends in Peru in 2016 and then analyzes the nature of several state institutions. The article is based on primary and secondary documents as well as several expert interviews in early 2017. The article concludes with a brief analysis of the quality of democracy in Peru, using Diamond and Morlino's (2005) framework that explores procedures, content, and results. The data suggest that democracy is firmly institutionalized in Peru after more than 15 years of competitive, free, and fair elections. In that sense, the country seems to have broken the cycle of swinging back and forth 
between democracy and non-democratic regimes. However, the quality of Peruvian democracy remains moderately low.

\section{NATIONAL TRENDS}

\section{Political Sphere}

The most important political event in Peru in 2016 was the change of administrations through the peaceful and competitive transfer of power from President Ollanta Humala (2011-2016), leader of Peru's Nationalist Party, to Pedro Pablo Kuczynski (PPK), leader of Peruvians for Change (Peruanos por el Kambio). ${ }^{1}$ Kuczynski is a technocratic economist who lived in the United States for decades and promoted neoliberal economic reforms from high-level positions in the World Bank and the Inter-American Development Bank. After serving in several cabinet positions in the Peruvian government between 2001 and 2006 under President Alejandro Toledo (2001-2006), PPK unsuccessfully ran for president for the first time in 2011.

In the first round of the election on 10 April 2016, ten candidates participated in the presidential bid (down from an original eighteen). In the end, no candidate received more than 50 percent of the vote, and Keiko Fujimori moved on to face PPK in the second round. Notably, the political parties of former presidents Alan Garcia (2006-2011) and Toledo underperformed in the elections. Further, as noted above, the JNE eliminated two candidates, one of whom was seen as a frontrunner, for alleged inappropriate campaign activities in the weeks before the elections. Critics of the JNE decision charged that the removal of two candidates, Julio Guzmán of All for Peru (Todos por el Perú) and Cesar Acuña of the Alliance for Progress (Alianza por el Progreso) was actually linked to the electoral challenge they posed to Keiko Fujimori rather than the alleged campaign violations.

Another important development in the first round was the rise of a relative newcomer to the national political scene, Verónika Mendoza, as the head of a leftist coalition called Broad Front for Justice (Frente Amplio). Originally from the region of Cusco and fluent in Quechua, Mendoza is popular in Peru's southern regions. Mendoza's support increased as the first round neared, and she ended up receiving 18.7 percent of the vote. Mendoza's coalition of leftist parties, which brought several factions of the left together to support her candidacy in the presidential election, won several seats in Congress. As the year progressed, signs of problems in the coalition emerged, and by the end of the year the alliance was very precarious. Nevertheless, the surge in popularity of Mendoza and the Frente Amplio stands out as a small win for Peru's left, especially given how extremely unpopular Humala's leftist government was 
during the final four years of his presidency, and the 2014 recall of Lima's leftist mayor, Susana Villarán.

Keiko Fujimori's continued electoral strength in the 2016 election also warrants further discussion. Keiko and her fujimorista party, Popular Force (Fuerza Popular) enjoyed high levels of support among Peruvians throughout the presidential campaign. In 2011 she made it to the second round as well, losing to Humala in a close race. Her popularity is inextricably linked to her father, who is currently serving a 25-year sentence for corruption and human rights abuses. Alberto Fujimori led the country from 1990 to 2000 as a strongman, manipulating democratic institutions to consolidate and centralize his power (McClintock 1993; Bowen 2000; Kenny 2004; Conaghan 2005; Burt 2007). His outsider status drew voters who were tired of established politicians and parties. The current party appeals to anti-establishment voters and garners support from many powerful socially conservative forces in Peru, such as the Catholic Church and several business sectors, including those associated with mining and external trade. Further, as analyst Maria Luisa Puig (2016, 22 April) explains, "[Keiko] Fujimori managed to secure such a strong showing in the first round due to her loyal base of supporters, largely among Peru's poor. She has managed to capitalize on her father's popularity: much of her backing comes from voters who believe that another Fujimori presidency would guarantee a strong economy and an improved security situation." She has successfully borrowed from his populist style, and her party is especially strong among Lima's poor and in rural areas. Keiko's consistent popularity, and the continued strength of her political party, represents one concern surrounding Peru's democratic progress, as many worry that she is supported by her father's "mafia." Critics charge that she would pardon her father if she won (although during the campaign she promised not to) and potentially revert to his authoritarian and extremely corrupt practices. Further, more progressive elements of the Peruvian electorate worry about her commitment to socially conservative policies.

During the second round of the presidential election, the Peruvian electorate's skepticism about Keiko's commitment to democracy and transparency led to several protests ("No a Keiko"). In an unprecedented move, the left (led by Mendoza) threw its support behind PPK, a center right candidate, to prevent Keiko from taking power (Dargent and Muñoz 2016). As new corruption allegations against Keiko emerged in the weeks before the second round, the polls showed her numbers falling; PPK barely won the presidential post, with 50.124 percent of the vote, a margin of slightly more than 41,000 votes, representing the closest electoral margin in recent history. Albeit extremely close, the win demonstrates the strength of the opposition to Fujimori as a candidate; parties from very different ideological perspectives joined forces to vote against Fujimori. This decision to join forces in support of a candidate viewed by many as very technocratic and lacking charisma is an important illustration of the commitment to democracy by many political parties and the electorate in Peru. 
Outside of the presidential race, the other noteworthy national political developments in Peru in 2016 pertain to the makeup of the legislature and cabinet, with implications for the passage and implementation of laws and policies, respectively. Although she lost the presidential race, Keiko's political party performed very well in the April Congressional elections, winning 73 of 130 seats in Peru's unicameral legislature. PPK's party performed poorly, winning just 18 seats. These results guaranteed a divided government, public battles, and legislative gridlock during the second half of the year.

At the level of the executive, in his first six months PPK's cabinet was more stable than that of his predecessor, which was completely reshuffled twice in 2015 alone (Muñoz and Guibert 2016). Nonetheless, two cabinet scandals in PPK's early months did occur. First, Defense Minister Mariano González stepped down due to allegations of an affair. Second, Congress voted to censure PPK's Education Minister, Jaime Saavedra. Fuerza Popular formed an alliance with APRA to lead this charge in Congress. They formally accused him of mishandling preparations for the 2019 Pan-American Games, scheduled to be held in Lima. Analysts in Peru argue that in reality he was being targeted for his ambitious education reform agenda, which included cracking down on for-profit educational institutions (whose investors often have close ties to congressional officials) and promoting gender equality in the educational curriculum. This case foreshadows what appears to be a strategy by the fujimorista party to destabilize and paralyze PPK's government.

Nationwide corruption scandals persist, a phenomenon that is closely tied to Peru's history of weak political institutions. One noteworthy case involved the wife of Ollanta Human, former First Lady Nadine Heredia, who faced allegations of money laundering for which she continues to be investigated. Public investigators prohibited her from international travel between June and October due to the charges, but as soon as the ban expired she moved to Geneva to accept a job with the Food and Agricultural Organization. Her move prompted a national scandal, as Peruvians perceived her to be evading justice. She eventually returned to the country, and by the end of 2016 the case was still open.

The largest corruption scandal in 2016, one that has rocked Peru as well as the greater Latin American region, is that of Brazilian construction firm Odebrecht. Allegations and concerns about Odebrecht surfaced throughout the year with regard to delays and expenses related to the construction of the Southern Gas Pipeline. In 2014, Odebrecht and several partners won a 34-year, multi-billion dollar concession to construct and manage the pipeline. When Odebrecht's president was arrested in Brazil because of his links to what is called the Lava Jato (Carwash) investigation, several international investigations followed. The Lava Jato investigation exploded on 21 December, when Odebrecht and a subsidiary, Braskem, entered a guilty plea in the United States for violating the Foreign Corrupt Practices Act. This plea opened the door to a series of corruption scandals that have implicated government officials at the highest 
levels in countries that include Brazil, Colombia, Peru, and Venezuela. As part of the case, Odebrecht admitted to paying \$29 million in bribes in Peru between 2005 and 2014.

The implications of the Odebrecht scandal in Peru were still just beginning to emerge at the end of 2016. Every sitting president since 2001, including PPK, may be implicated. The scandal has varied consequences for democratic governance in Peru. On one hand, the information revealed in the case has led to serious efforts to investigate and charge high-level officials involved in receiving potential kickbacks and exerting their influence over the bidding process, suggesting that Peruvians are serious about attacking this problem. On the other hand, the fact remains that the scandal erupted due to an investigative process that took place outside of Peru, not within, which highlights the overall ineffectiveness of combating corruption from within Peru's institutions. Looking forward, as Peruvians continue to investigate the Brazilian firm's business dealings in the country, 2017 promises to be an important test of how PPK's government can attack corruption in Peru.

In sum, the change in national government positions brought a new president to power. However, corruption scandals and legislative gridlock due to the power of Keiko Fujimori's block in Congress prevented PPK from emerging as an effective president during his first months in office.

\section{Economic Sphere}

An additional challenge confronting Peru is the economy, which only grew at an estimated 3.8 percent in 2016 (see Figure 1), the fourth consecutive year with less than 4 percent growth. The slowdown is linked to a continued downturn in international commodity prices, as much of Peru's economic growth in the past decade has been generated by the mining sector (de la Torre et al. 2016). Although poverty rates continued to fall, the pace of decline has slowed, indicative of the continued economic slump (see Figure 2). 
Figure 1. Peru's GDP Percent Annual Growth*

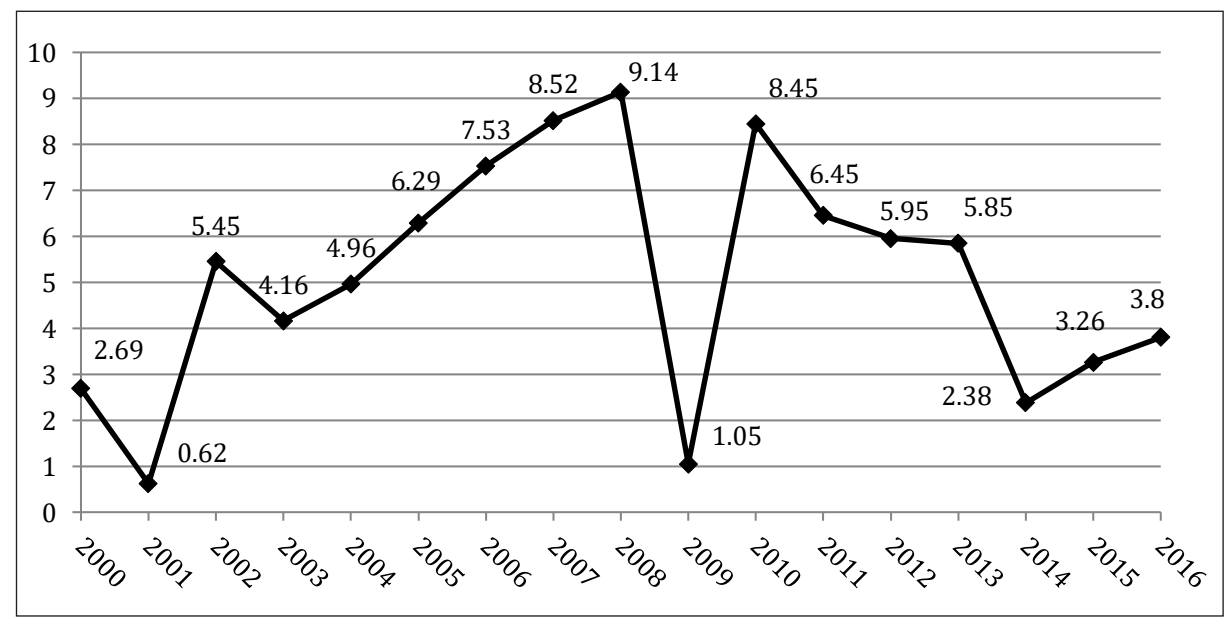

*Data for 2016 are projected.

Source: http://www.bcrp.gob.pe/estadisticas.html

PPK ran for President on promises to stimulate the economy with infrastructure projects and tax reform. However the political gridlock with Congress has made it difficult for him to implement policy reform. The corruption scandals that erupted throughout the year also have the potential to impede foreign investment. Therefore, at the end of 2016 the economy had made little progress toward achieving more rapid growth.

Figure 2. Poverty Rates in Peru (\%), 2004-2015

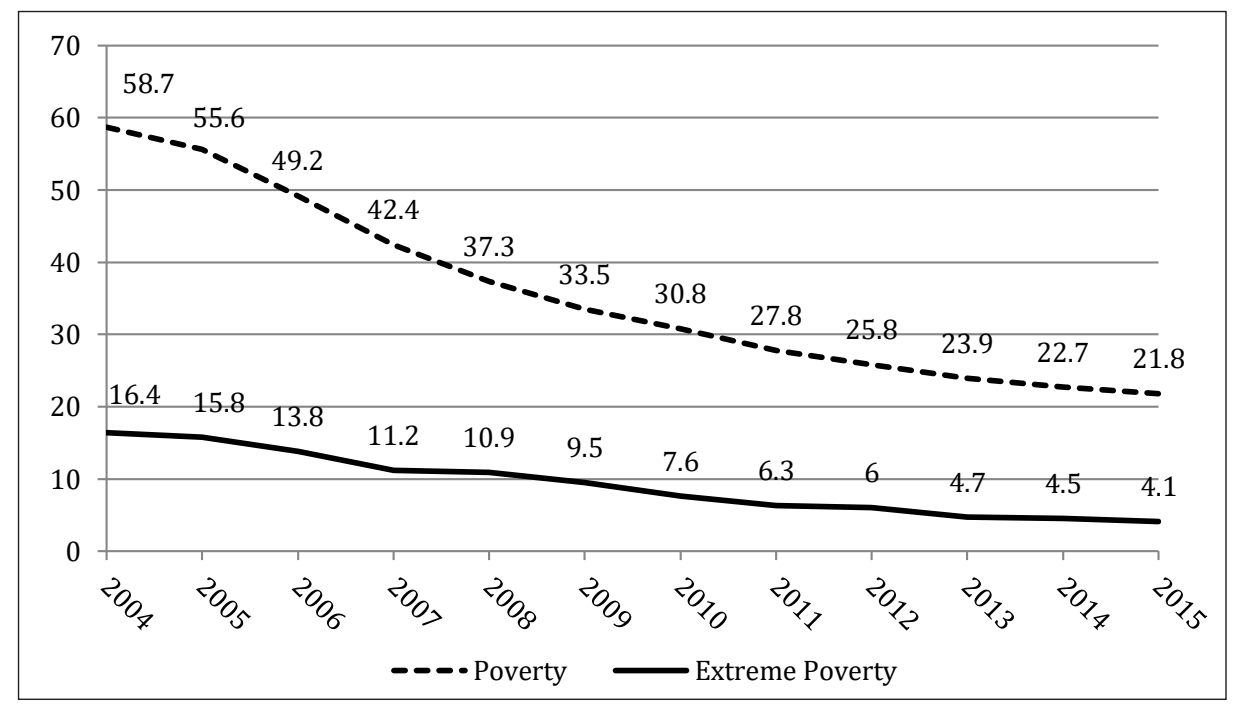

Source: INEI, http:/ / www.inei.gob.pe/ 


\section{Social Sphere}

Social inclusion and stability are central to understanding the quality of democracy in Peru. In this area Peru continued to experience high levels of conflict and exclusion, although some noteworthy changes did take place in 2016. Further, the strength of the fujimorista block impedes change in social policy areas, such as reproductive rights and marriage equality, due to their alliances with socially conservative forces in the country.

According to the polling firm IPSOS-Peru, the most serious problems facing the country continue to be the lack of citizen safety and pervasive corruption (IPSOS 2016c; see Carrion et al. 2015 for longer-term data). In July 2016, an IPSOS-Peru survey (2016b) reported that only 24 percent of the respondents approve of Congress, and a mere 23 percent approve of the judicial branch. This reflects the ongoing decline in already low levels of support for these institutions in Peru (see Table 1). This distrust in and dissatisfaction with state institutions reinforce the lack of legitimacy of the Peruvian state in the eyes of its citizens.

Table 1. Percent Approval for Congress and the Judicial Branch, 2016-2014

\begin{tabular}{ccc}
\hline Date & Congress & Judicial Branch \\
\hline 2014 & 27.4 & 34.2 \\
2012 & 36.6 & 39.4 \\
2010 & 31.9 & 37.5 \\
2008 & 33.2 & 33.9 \\
2006 & 32.6 & 32.6 \\
\hline
\end{tabular}

Source: Carrion et al. 2015.

Social conflicts continue to plague Peru, most of which are linked to citizens' discontent with mining activities around the country. ${ }^{2}$ Although the number of conflicts has slowly decreased since 2010, the rate of this reduction has stalled in recent years and the overall numbers remain high (see Figure 3 ). At the end of 2016, the Peruvian Ombudsman's office reported a total of 212 conflicts across the country, 156 of which were classified as active. Of the conflicts, 68.9 percent were related to environmental concerns, often leading to protests against the national and regional governments. For example, in the Apurímac region, community members continued to protest the "Las Bambas" copper mining project, which is managed by the Chinese mining firm MMG Limited (Muñoz and Guibert 2016). Communities close to the mine have accused the company of breaking promises regarding transportation routes and the environment. 
Protests turned violent in 2016, leading to the death of a handful of activists in clashes with the Peruvian national police.

PPK's government, like Humala's, has not taken a strong stance against mines like MMG Limited due to the power of the mining sector and the country's economic dependence on mining. More broadly, it seems that PPK lacks a strategy for reducing mining conflict. His inability to resolve the long-standing Las Bambas conflict, for example, led Eduardo Ballón, president of Grupo Propuesta Ciudadana, to argue that PPK's government does not have an effective plan in place to address the high level of social conflict in Peru (Loayza 2016, 19 October).

Figure 3. Number of Social Conflicts, 2010-2016

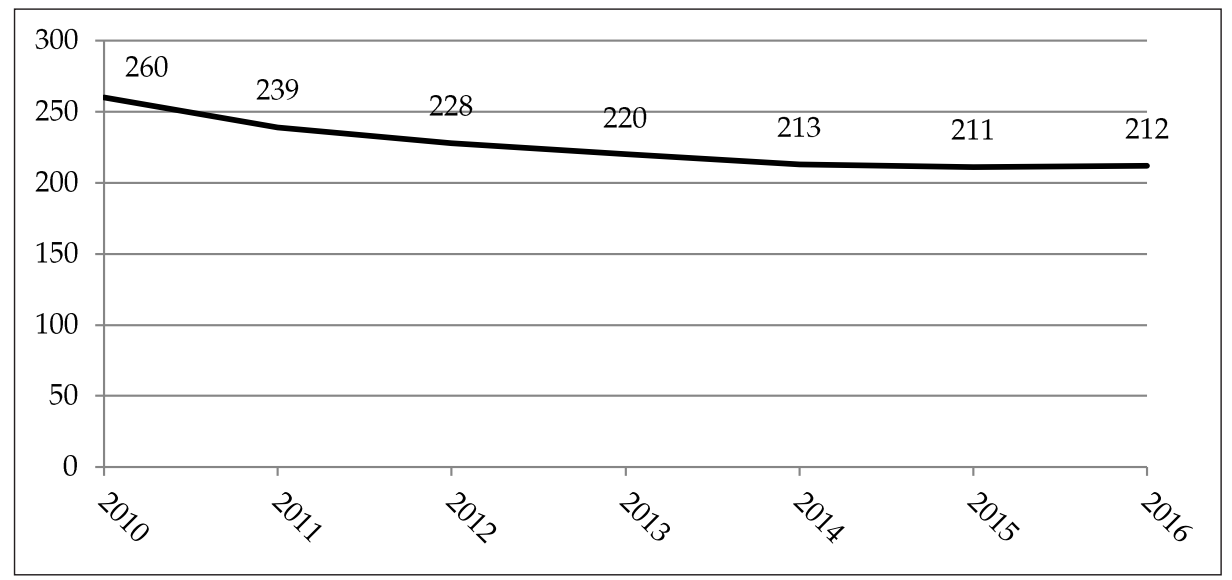

Source: Defensoría del Pueblo, http://www.defensoria.gob.pe

Another issue that continued to be important in Peru in 2016 was the inclusion of historically marginalized groups in the social and political spheres. Peru has witnessed an unprecedented reduction in poverty and improvement in social development indicators over the past decade. It is worth noting that Humala's government promoted a series of reform efforts that prioritized inclusion and social development. This was possible due to the economic boom that Peru experienced for many years, with relatively high rates of growth in overall GDP (see Figure 1). PPK pledged to continue to fight poverty and improve social services like education and health care. However, several groups in Peru still experience discrimination and exclusion.

Women face higher levels of unemployment than men and a wage gap persists. Additional problems facing women in Peru are domestic violence, human trafficking, and femicide. For example, the Global Slavery Index places Peru in fifth place in Latin America in terms of human trafficking, below Colombia, the Dominican Republic, Guatemala, and Haiti (The Walk Free Foundation 2016). 
The majority of the victims in Peru (up to 90 percent) are women and girls. While Peruvian police have been more successful in recent years in capturing traffickers, there is still a very high level of impunity in the judicial process. Capital Humano y Social Alternativo (2016), an NGO that documents human trafficking trends in Peru, asserts that only three of 100 accused traffickers are convicted and sentenced during the judicial process.

Peru has relatively high levels of femicide as well. In 2013, 83 women were killed by their partners or former partners in Peru. This number rose to 90 in 2014, according to the latest report of the Gender Equality Observatory of Latin America and the Caribbean of ECLAC (n.d.). Between January and June 2016, the Ministry of Women and Vulnerable Populations (Ministerio de la Mujer y Poblaciones Vulnerables, MIMP 2016) reported 118 potential cases. These statistics suggest that the problem is quite severe.

In response to these troubling trends, on 13 August 2016 more than 100,000 Peruvians took to the streets across the country to protest gender violence and discrimination. The "Not One More" (ni una menos) protest took place when two particularly appalling cases of domestic violence seized the nation's attention. A movement emerged, using Facebook to share stories and plan a national mobilization. According to people who marched in Lima, the streets were packed with men, women, and families. The event was peaceful, and the police who were monitoring the event even showed their solidarity by wearing white gloves. Prominent national politicians, including PPK and his family, marched as well.

Ilustration 1. "Ni una menos protest" in Lima, Peru.

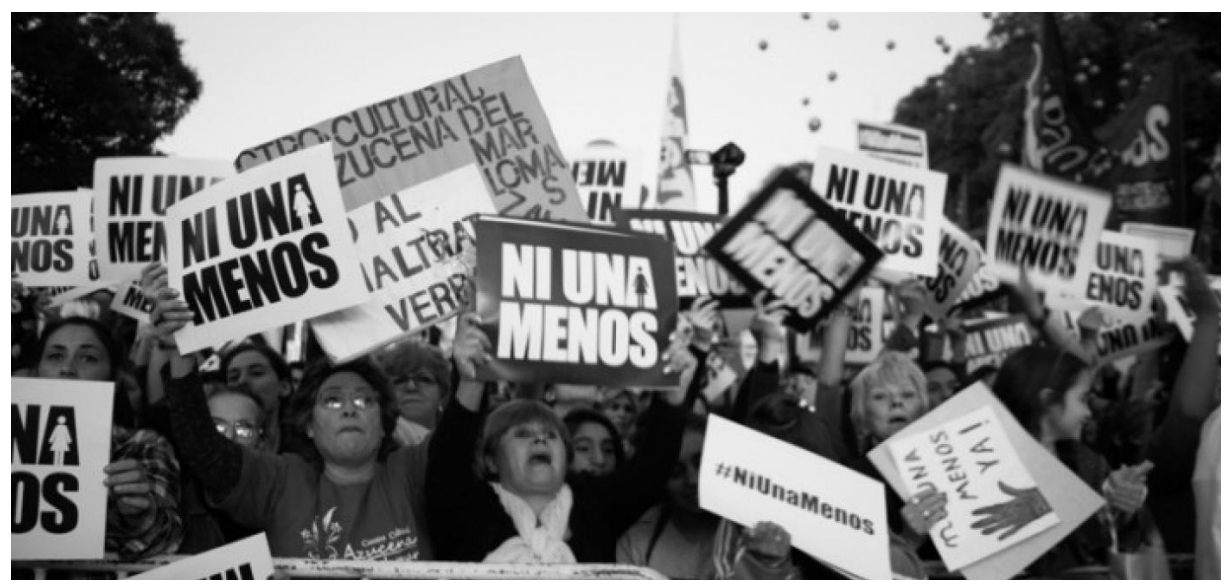

Photo courtesy of Radio Nacional Peru, http:/ / www.radionacional.com.pe/

The protest brought even more national attention to gender discrimination in Peru. One short-term effect of the mobilization was that the number of reports of domestic violence reports increased significantly. Immediately after the march, 
the Ministry of Women and Vulnerable Populations reported that femicide reports had increased by 125 percent in just a few weeks and domestic violence complaints had increased by 40 percent (Kanashiro Fonken 2016, 20 September). Activists assume that this is due to the fact that women felt empowered to seek help in these cases.

Similar to women in Peru, indigenous and Afro-Peruvian populations also took measures to fight discrimination in 2016. Nonetheless, their high levels of exclusion have remained relatively unchanged. The Ministry of Culture has recognized 55 native communities in Peru's Amazon region and in the country's highlands, though data about indigenous communities are still relatively scarce. These populations often have reduced access to public services, including education and health services, and when access does exist, services are of low quality. The National Statistics Institute (INEI 2008) undertook a census of the communities in 2007, finding, for example, that 14.1 percent of the indigenous communities do not have a school; among schools that do exist, most are elementary schools. The same study found that 63.3 percent of these schools do not have running water, and 73.4 percent do not have electricity. A majority of indigenous communities (59.1 percent) do not have healthcare centers. Data show that higher levels of poverty exist among the Peruvians who speak Quechua, Aymara, and Amazonian languages.

One effort to empower indigenous communities lies in what is called prior consultation (consulta previa), which refers to the right of indigenous and ethnic groups to be consulted on matters affecting their culture and heritage. Peru, which signed onto the Indigenous and Tribal Peoples Convention (known as ILO 169), passed a law in support of this process in 2011. In practice, however, the implementation has been weak, mostly because the decisions that emerge from the process, when consultations do take place, are not binding. Thus, to date, the process has not led to genuine empowerment of native communities to be part of decisions about their ancestral lands in Peru (Jaskoski 2014; , Sanborn and Paredes 2014; Sanborn et al. 2016).

To improve the political participation of women and indigenous communities, quotas have been put in place in almost every electoral process. Women must make up 30 percent of the candidates on all party lists, and, in areas with a high concentration of indigenous communities, indigenous candidates should make up 15 percent of the list. However, despite these measures, women and indigenous people remain underrepresented in most levels of government. For example, only 2-3 percent of mayors are women. Similarly, in the 2011 regional elections, only 12 indigenous candidates were elected to the regional councils (Espinosa De Rivero 2012). In the 2014 local and municipal elections, only 1 percent of the 12,502 elected officials identified as indigenous. Congress has had very few indigenous members since 2000 (Centro de Culturas Indígenas del Perú 2016). This persistent underrepresentation frequently results from the fact that although electoral quotas are enforced, members of marginalized groups usually are featured at the bottom of party lists. 
The reality for Afro-Peruvians, who represent an estimated 3 percent of the population, did not improve much in 2016, either. There is no official record of the total number of Afro-Peruvians, however, the few existing studies on the topic show that Afro-Peruvians earn less and have reduced access to education compared to the national average (Benevides et al. 2016). One accomplishment for Afro-Peruvian (and indigenous) activists in 2016 was the inclusion of a question about citizens' self-identification, with several racial and ethnic categories, in the 2017 census. Proponents of this change argue that more exact data about the indigenous and Afro-Peruvian communities will lead to public policies that better target these groups.

In terms of the LGBTQI population, advances have been achieved in a relatively short amount of time. In 2015, Peru's first openly gay Congressman Carlos Bruce presented a law that would allow civil unions in Peru. Many high-level politicians, including President Humala, opposed the bill, and it did not make it out of the Congress' Justice Committee. Religious groups also adamantly opposed these efforts. However, the efforts did trigger a national conversation on the rights of LGBTQI Peruvians. In 2016, PPK announced that he did not oppose same-sex civil unions during his campaign (although he has not been consistent about his stance since then). In 2016, Congressmen Bruce and de Belaunde resubmitted a bill to allow same sex civil unions, which will be debated in 2017. In another breakthrough for the LGBTQI community, in October 2016, the Supreme Court reversed a previous decision, ruling that being transgender is not a "pathology." Thus, although there is still a high level of discrimination against LGBTQI individuals (Jaime 2016), these advances have led to some significant changes regarding how gender is perceived and categorized in the country (Orbegozo 2016, 30 December).

In sum, there is still a long way to go toward the full inclusion of marginalized social groups in Peru. However, 2016 did bring some interesting changes, especially in the area of gender equality.

\section{International and Regional Trends}

In general, Peru enjoyed relatively peaceful relations with its neighbors and other countries in the Americas in 2016. For example, a tense border dispute between Chile and Peru that took place in 2015 was largely resolved (Muñoz y Guilbert 2016). A major effort of the Peruvian government continued to be the promotion of trade agreements and trade relations. In February, Peru signed on to the Trans-Pacific Partnership (TPP), in an illustration of PPK's pro-trade views. In December 2016, after United States President elect Donald Trump vowed to withdraw support, PPK argued internationally that a new agreement should be pursued, preferably involving China. Peru also hosted the Asia-Pacific Economic Cooperation (APEC) Economic Leaders' Conference in November, 
which included a visit by U.S. President Barak Obama (2008-2016). PPK also stood out internationally for being a firm supporter of Venezuela's opposition and publically encouraging dialog as a resolution to the crisis facing Peru's South American neighbor, a position that has occasionally led to diplomatic barbs with President Maduro. Finally, PPK's administration intentionally reverted back to the practice of assigning key diplomatic positions to career diplomats.

The results of the 2016 presidential elections and PPK's commitment to neoliberalism can be placed in the larger regional debate about the continued pushback of Latin America's "pink tide" around Latin America. Since the rise of Venezuelan President Hugo Chavez (1999-2013), scholars have pointed to a resurgence of Latin America's leftist politicians, after having been largely discredited around the region during the Cold War (Casteñeda 2000; Cameron and Hershberg 2010; Levitsky and Roberts 2011). An important motor behind that trend is citizen discontent around the neoliberal reforms that swept the region in the 1980s and 1990s. Importantly, however, most of the leftists in Latin America have remained faithful to economic models that promote open markets and free trade policies. A decade later, it became apparent that, although the left had regained strength, the right had proven to be a resilient political force (Dominguez, Lievesley and Ludlam 2011; Luna and Kaltwasser 2014). The continued and enduring focus on increasing-and not necessarily redistributing - wealth was never completely abandoned.

Peruvian economic and political trends have, in some ways, mirrored this regional trend. Leftist Ollanta Humala rose to popularity and first ran for president in 2006, with a nationalist platform that stressed the need for social justice reforms. After moderating his stance considerably in the 2011 electoral period, he did continue to profess some leftist ideas, such as the need to reduce inequality and expand social programs. As president he continued the neoliberal economic politics that had been put in place in the 1990s while also expanding the social safety net. However, Peru's 2016 election demonstrated the continued power of the right in Latin America as well. Both presidential candidates in the second round of the election and the majority party in Congress in Peru are committed to neoliberalism and fall to the center or right of the ideological spectrum. This should ensure that Peru maintains its neoliberal agenda for at least the next five years.

\section{INSTITUTIONAL ANALYSIS}

The previous section alluded to the fact that weak state institutions have been a major impediment to improved democratic governance in Peru. This section takes a closer look at the branches of government and how they evolved in 2016 to ilustrate some of the problems in more depth. 


\section{Executive Power}

Peru's executive branch is relatively powerful, however presidents themselves tend to be weak. The most important change in the executive branch in 2016 was the transfer of power from Humala to PPK. When analyzing the governmental dynamics of the two leaders, the year varied in some ways. The first half of the year was marked by instability and disruption of the cabinet-which, as discussed, was not new to the Humala administration that year. In contrast, the Executive Branch under PPK appeared to be more professional and slightly more stable, although some scandals and reshuffling have occurred (as noted above).

Like his predecessor, however, PPK finished 2016 with declining approval ratings that dipped to 48 percent in December (see Figure 4). This represents one of the sharpest drops in a president's approval rating during the first six months in recent history. For example, Humala's approval rating did not fall this low until his eighteenth month in power (Muñoz and Guibert 2016). In surveys, respondents report that their disapproval lies in concerns that PPK has not improved public security or reduced corruption enough (IPSOS 2016a). Critics also charged him with being weak and ineffective when facing a hostile Congress. For example, although legally PPK could have called a vote of no confidence during the censure process of Minister Saveedra, the president chose not to do so. In PPK's mind, this choice preserved democracy; for critics, it was a sign of weak leadership.

Figure 4. Presidential Approval Rates (\% surveyed), 2016

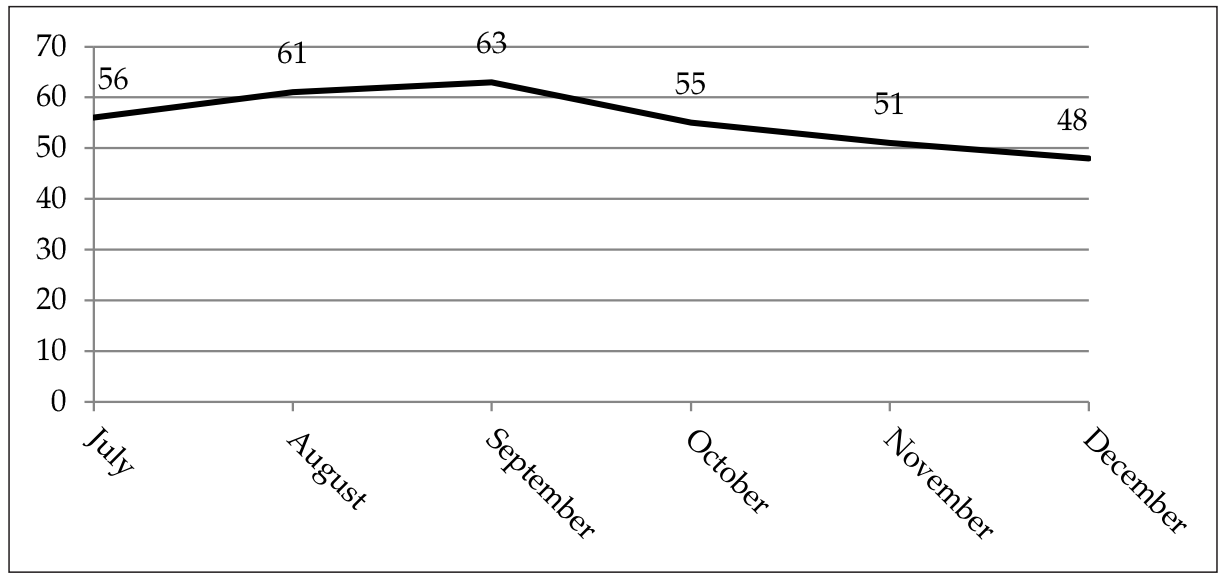

Source: http://www.ipsos.pe/opinion_publica 
2017 will be an important year for PPK and his cabinet to demonstrate to Peruvians that their government can follow through on campaign promises. If PPK does not follow through, then he is sure to continue to fall prey to the low approval rates that almost every president since Alejandro Toledo has experienced throughout their time in office (Barrenechea and Villagarcia 2014).

\section{Legislative Power}

The legislative body in Peru is notoriously weak, and this did not change in 2016. As noted above, the major legislative changes in 2016 took place on 10 April, when Peruvians elected a new Congress. In terms of composition, 27.7 percent of the 2016-2020 members are women, an increase from 21.5 percent in 2011 (IPU n.d.). However, only one indigenous member was elected, down from two during the previous term. This low number reflects the severe underrepresentation of indigenous people in Peru (Centro de Culturas Indígenas del Perú 2016).

The new congressional make-up did, however, reinforce some noteworthy trends. First, as noted above, Keiko Fujimori's political party has a clear majority in Congress, with 56 percent of the seats, which means that the party can easily block reforms and only needs a few more allies to garner a supermajority when needed. Because PPK's party has limited representation in the legislative body, divided government, gridlock, and political battles between the legislative and executive branches dominated the latter half of 2016.

Second, beyond gridlock, Congress is plagued by the ongoing weakness of political parties, a phenomenon that analysts and Peruvian citizens have lamented for decades. Peruvian political parties are ephemeral and personalistic, forming for elections around a political personality, then dying out quickly. This dynamic has led analysts to call Peru a "democracy without parties" (Levitsky and Cameron 2003; Tanaka 2005; Levitsky 2013).

The 2016-2020 Congress already exhibits the continued problems with political parties in Peru. As Muñoz and Guibert (2016: 330) documented in last year's annual summary, the previous Congress regularly suffered from party switching (transfugismo). Table 2 illustrates this trend. In 2011, Peruvians elected 130 Congresspeople from six political blocks (or bancadas), a block being a loosely allied set of political parties that agree to work together on a common agenda. By the end of the congressional period in 2016, the number of blocks had expanded to nine due to party switching. In the new 2016 Congress, the blocks had almost completely changed. Notably, however, the only block that continued to have representation from 2011 to 2016 and into the new Congress is Keiko Fujimori's party (in bold in Table 2).

Another problem facing the legislative branch in Peru in terms of its power is the relative inexperience of most members. In the 2011-2016 legislative period, more than 80 percent of the members of Congress were new to their positions 
(Levitsky 2013). In the new term, 73 percent of legislators have no previous legislative experience (Asociación Civil Transparencia 2016). This large number of relatively inexperienced politicians often reinforces short-term thinking and weak policy platforms.

The legislative body did pass several laws in $2016,{ }^{3}$ but there were no major reform initiatives such as the civil service reform (called SERVIR) that had taken place in recent years. This lack of major reforms in a calendar year is unusual in Peru, where politicians tend to promote several major institutional overhauls every year (Barrenchea and Villagarcia 2014; Muñoz and Guibert 2016). The unusual case of 2016 is probably due to a combination of factors. In an electoral year, lame duck legislatures tend to avoid major reform initiatives. Also, by the end of the year, PPK had not yet presented major reforms proposals, perhaps due to the fact that he it was still early in his term and he faced a divided and outright hostile Congress. He also often reminds citizens that Peru has many laws on the books and major reforms may not always be what the country needs. Instead, he has promised to improve the implementation of many existing laws and policies.

Importantly, however, there is consensus among political forces that several major reforms are needed in Peru, such as electoral reform, political party reform, and judicial reform. Looking ahead, we should expect PPK and Congress to push for some major reforms, specifically judicial reform, which was a campaign promise for PPK. Therefore, 2017 promises to be a busy year in terms of legislative activities. 
Table 2. Analysis of Peruvian Congress Political Blocks Over Time

\begin{tabular}{|c|c|c|c|c|c|}
\hline 2011-2012 & & 2015-2016 & & 2016-2017 & \\
\hline Name of Party & $\begin{array}{c}\text { \# of } \\
\text { Seats }\end{array}$ & Name of Party & $\begin{array}{l}\text { \# of } \\
\text { Seats }\end{array}$ & Name of Party & $\begin{array}{l}\text { \# of } \\
\text { Seats }\end{array}$ \\
\hline $\begin{array}{c}\text { Fujimorista } \\
\text { Parliamentary Group }\end{array}$ & 37 & $\begin{array}{c}\text { Fujimorista } \\
\text { Parliamentary Group }\end{array}$ & 34 & $\begin{array}{c}\text { Popular Force } \\
\text { (formerly Fujimorista } \\
\text { Parliamentary Group) }\end{array}$ & 73 \\
\hline Peru Wins (Gana Perú) & 47 & Peru Wins (Gana Perú) & 27 & $\begin{array}{l}\text { Broad Front (Frente } \\
\text { Amplio) }\end{array}$ & 20 \\
\hline $\begin{array}{l}\text { National Solidarity } \\
\text { (Solidaridad Nacional) }\end{array}$ & 8 & $\begin{array}{l}\text { National Solidarity } \\
\text { (Solidaridad Nacional) }\end{array}$ & 7 & $\begin{array}{c}\text { Peruvians for Change } \\
\text { (Peruanos por el } \\
\text { Kambio) }\end{array}$ & 18 \\
\hline $\begin{array}{l}\text { Parliamentary } \\
\text { Concertation } \\
\text { (Concertación } \\
\text { Parlamentaria) }\end{array}$ & 6 & $\begin{array}{l}\text { Parliamentary } \\
\text { Concertation } \\
\text { (Concertación } \\
\text { Parlamentaria) }\end{array}$ & 9 & $\begin{array}{l}\text { Peru's Alliance for } \\
\text { Progress (Alianza para } \\
\text { el Progreso del Perú) }\end{array}$ & 9 \\
\hline $\begin{array}{c}\text { Alliance for Change } \\
\text { (Alianza por el Gran } \\
\text { Cambio) }\end{array}$ & 12 & Perú Posible & 11 & $\begin{array}{l}\text { Popular Action } \\
\text { (Acción Popular) }\end{array}$ & 5 \\
\hline \multirow[t]{5}{*}{$\begin{array}{l}\text { Parliamentary } \\
\text { Alliance (Alianza } \\
\text { Parlamentaria) }\end{array}$} & 20 & $\begin{array}{c}\text { Dignity and } \\
\text { Democracy (Dignidad } \\
\text { y Democracia) }\end{array}$ & 12 & $\begin{array}{l}\text { Popular Alliance } \\
\text { (Alianza Popular) }\end{array}$ & 5 \\
\hline & & $\begin{array}{c}\text { Popular Action and } \\
\text { Broad Front (Acción } \\
\text { Popular-Frente } \\
\text { Amplio) }\end{array}$ & 8 & & \\
\hline & & $\begin{array}{l}\text { Christian People's } \\
\text { Party (Partido Popular } \\
\text { Cristiano)-_Alianza } \\
\text { para el Progreso } \\
\text { (Alliance for Progress) }\end{array}$ & 7 & & \\
\hline & & $\begin{array}{l}\text { Regional Union } \\
\text { (Unión Regional) }\end{array}$ & 6 & & \\
\hline & & $\begin{array}{l}\text { Special group with no } \\
\text { formal name }\end{array}$ & 9 & & \\
\hline Total Seats & 130 & & 130 & & 130 \\
\hline
\end{tabular}

Sources: Asociación Civil Transparencia (2016: 4); Muñoz and Guibert (2016: 330).

In sum, Congress continues to face serious institutional problems in Peru. Weak political parties and inexperienced politicians prevent robust policy platforms from moving forward. Looking ahead, these problems will remain a major challenge to improving the quality of democracy in the country through the pending reform efforts. 


\section{The Judiciary}

There were no major changes in the judicial branch of government in 2016. One notable event involving the judicial system was a two-month strike at the end of the year to the demand higher salaries. This strike, which has since been resolved, left the courts even more backed up than they already were.

As noted above, Peruvians are very critical of the judicial branch. In fact, Peruvians distrust the judicial branch more than citizens in any other country in Latin America (Carrion et al. 2015). Thus, there is a general consensus in Peru that this branch is in need of serious reform. Deep-rooted problems with this system allow crime and corruption to flourish. Poorly trained and underfunded police work with an Attorney General's office that has been plagued by corruption scandals. There is a public perception that illegal networks in the judiciary involve the highest-level officials. Impunity prevails. The judicial branch's handling of the Odebrecht scandal will test the system's ability to handle the corruption that has permeated the state all the way to the very top.

\section{INTERGOVERNMENTAL RELATIONS}

\section{Relations Between the Branches}

With the judiciary so weak, tensions between the legislature and the executive have been heightened in Peru. The first major confrontation lay in Congress' censure of PPK's Education Minister. However, public battles took place all year. These tensions led Cardinal Juan Luis Cipriani to call a closed meeting between PPK and Keiko Fujimori in December. With Cipriani mediating, the goal of the meeting was to reduce tensions between the leaders, who had failed to meet privately since the July election.

\section{Relations Among Levels of Government}

Relations among levels of government—central, regional, and municipal—are also strained. Peru underwent a comprehensive decentralization process in 2001. The process, which continues to unfold, ${ }^{4}$ has changed Peru irrevocably. Indicators show that the reform is institutionalized; reversing it would be extremely difficult. For example, public investments at the local and regional levels increased substantially during the 2007-2013 period. Municipal public investment budgets went from $\$ 2,214,000,000$ USD to $\$ 7,179,000,000$. USD Regional public investments also increased significantly, going from $\$ 1,500,000,000$ USD to $\$ 3,036,000,000$ USD (Guerra García 2015). Since 2002,

For more in depth analyses of decentralization see McNulty (2011), Prodescentralización (2011) and (2015), Controlaría General de la República (2014), and Zas Fris (2005). 
subnational governmental elections have taken place regularly and without incident. Regional political parties have gained strength, and many of them now hold national political positions. Analysts document that economic growth in regions around the country has led to improved indicators of human development (ANGR 2014).

Despite these transformations, 15 years after the reform process began, many Peruvians are pessimistic about the state of decentralization, fearing that the process has stalled and there is little political will to move it forward. Since the decentralization reform, citizens perceive very high levels of corruption in subnational governments (ANGR 2014; Muñoz 2014; Carrion et al. 2015). Further, many citizens blame subnational governments for failing to deliver basic services effectively, especially in rural areas. For example, in areas where transportation is extremely difficult, teachers have difficulties getting to their schools and sometimes do not even show up.

Strengthening decentralization was not a major piece of the presidential candidates' platforms, which suggests that little energy will be spent on improving the process in the coming years. Two of the most pressing problems are the central government's continued recentralization of the national budget and poor relations and communication mechanisms across the various levels of government (Muñoz 2014). Recentralization of the budget began to take place under the Humala administration (see Table 3), despite criticism from decentralization experts (ANGR 2015; Baca 2016).

Table 3. Percent of Total National Budget (Projected Budget) ${ }^{5}$

\begin{tabular}{ccccc}
\hline Level of Government & 2004 & 2008 & 2015 & 2017 \\
\hline National & 77 & 68 & 73 & 74 \\
Regional & 15 & 17 & 15 & 15 \\
Local & 8 & 15 & 12 & 11 \\
Total & 100 & 100 & 100 & 100 \\
\hline
\end{tabular}

Sources: Participa Perú (2005); ANGR (2014), Baca (2016).

Relations among municipal, regional, and national government offices are often characterized by either a lack of communication or poor coordination (Muñoz 2014). For example, there is still confusion across all levels of government and

The Peruvian government tracks the "original" budget (called Presupuesto Institucional de Aperatura, or PIA), which is the projected budget that is approved for each level of government during the previous fiscal year, and the modified (Presupuesto Institucional Modificado, or PIM), which is the finalized version by the middle of the budget year. 
the different national ministries when it comes to roles and responsibilities. Although the functions are delineated in the legal framework, several institutions are sometimes tasked with the same function. Subnational government officials, especially at the regional level, often claim that national officials attempt to control their spending. Regional governments also express frustration with the Ministry of Economics and Finance, or MEF. A general perception exists among regional officials that the MEF does not trust subnational governments to make sound spending decisions and therefore creates bureaucratic obstacles that the national government ministries do not face. Additional coordination problems can exist between municipal and regional governments, especially when the leaders of a region or city are not the same political party. This dynamic mostly manifests itself in the area of infrastructure spending, as infrastructure projects may not be coordinated for larger impact.

One important phenomenon that has continues is the growing strength of regional political parties, called regional movements in Peru (see Grompone 2016). Since the 2006 subnational elections, regional movements have been gaining gubernatorial seats every election and national parties have been losing power (López Ricci 2014; Prodescentralización 2015). This has exacerbated coordination problems between different levels of government as well as among regional governments. Another problem facing regional governments is corruption; by the beginning of 2017, more than half of the regional governors were under investigation for corrupt acts.

Thus, deep-rooted problems with institutions continue to plague the executive, legislative, and judicial branches of government in Peru. Subnational governments also face several problems, including poor coordination and corrupt officials. No noteworthy events occurred during 2016 to alter this situation.

\section{GENERAL EVALUATION OF THE QUALITY OF DEMOCRACY IN PERU}

2016 proved to be an interesting year, bringing some changes and much continuity. The national elections demonstrated the resilience of the right in Peru, through the election of PPK and the continued strength of the fujimorista movement. At the same time, myriad actors who oppose Keiko Fujimori and her party came together in opposition to her candidacy in the second round of the presidential election, ensuring PPK's win in the closest presidential election in Peru's democratic history. This win ensured a polarized citizenry and divided government in years to come. At the same time, Peru experienced continued problems low levels of economic growth, corruption, weak political parties, and ineffective state institutions. These problems will surely dominate the agenda in 2017. 
What does the analysis above tell us about the quality of democracy in Peru? Diamond and Morlino (2005) argue that to determine the quality of democracy, we should explore three areas: procedures, results, and content (see also IDEA 2016). Procedural quality rests on a "strong, vigorous, diffuse, and self-sustaining rule of law," active participation in the public sphere, "electoral competition between different political parties," and vertical accountability (Diamond and Morlino 2005: xiv-xix). Content refers to the substance of democracy, specifically levels of freedom and equality. And results can be viewed as a regime that meets the citizens' expectations and needs. Given their framework, the analysis above suggests that while democracy as a set of norms and procedures does appear to be fully institutionalized (i.e., there is very little threat of non-democratic actors rising to power), the quality of democracy in Peru remains relatively low. This section briefly explores the three areas to support this argument.

\section{Procedures}

Procedurally, Peru has been moderately successful in working toward improving the quality of democracy. The 2016 electoral process suggests that democratic procedures are institutionalized in Peru. The successful succession of several elected governments since the fall of the Fujimori regime in 2000 represents a break from Peru's lengthy history of swinging back and forth from democratic to authoritarian regimes. Elections have been competitive, free and fair since 2001. One red flag with regard to competitive and fair democratic procedures in 2016 is the JNE decision to disqualify two candidates just weeks before the first round. Critics charge that the JNE overreached its mandate and made the decision based on political, not technical, criteria. However, in the end this decision did not trigger an electoral crisis, and the procedural aspects of democracy in Peru remain intact.

Rule of law continues to be very problematic in Peru, however. Citizens view crime and corruption as the two most pressing national problems, and the judicial branch has failed to effectively attack these complicated issues. Transparency International (2017) ranked Peru 101 out of 172 in its 2016 Corruption Perception Index, which is right in the middle of the other South American countries.

\section{Content}

Broadly speaking, Peruvians enjoy high levels of individual freedoms. Freedom House (various years) has consistently ranked Peru as "Free" since 2002. When breaking down the analysis to explore political rights and civil liberties, Freedom House highlights several problems that detract from the quality of these freedoms, such as exclusion, corruption, high levels of crime and violence, and weak political parties. Thus, while freedom is not at risk, it does face challenges. 
Equality, on the other hand, is a more serious problem in Peru. Income inequality continues to plague the country and has proven very difficult to attack in recent years. Although Figure 3 above demonstrates that poverty levels have declined significantly, reductions in the Gini Coefficient have stalled. World Bank data (various years) show that from 2000 to 2010, the Gini Coefficient went from 50.77 to 45.11 , but the Gini Coefficient has dropped only slightly in more recent years, hovering at 44.14 in 2014 (the last year that data are available as of this writing). The discussion of the social and economic spheres above also demonstrates that the discrimination and exclusion of the historically marginalized continues to be persist.

\section{Results}

Is the state generating results that satisfy citizens? Diamond and Morlino use citizen support for democracy as an indicator of the results that emerge from democratic regimes. In Peru, support for democracy is slowly declining. According to Latinobarómetro (2016), in 2016 only 53 percent of Peruvians agreed with the statement that democracy is preferable to other forms of government, which represents a slight decline from the previous year. Peruvians also report low levels of confidence in their institutions and trust in their government, and most of these perceptions have also been getting worse with time (Latinobarómetro 2016).

\section{CONCLUSION}

This brief analysis of the three areas of quality democracies clearly suggests that Peru had a low to moderate level quality of democracy as of the end of 2016. This analysis complements Peruvian scholars' Paola Muñoz (2014) and Jorge Aragon's (2016a and 2016b) assessments of democracy in this Andean country. Of course, the analysis is not exhaustive, and future work should continue to explore the areas in more depth. Nonetheless, this analysis lends support to the argument that it is imperative that Peruvians effectively address the problems of weak institutions-including Congress, the judiciary, and political partieshigh levels of corruption, and stalled economic growth. Doing so would ensure that 2017 will bring many more changes, for the better.

\section{REFERENCES}

Aragón, Jorge. 2016a. "Representación política en los países andinos: crisis y recuperaciones." Revista de Ciencia Política y Gobierno 3(5): 107-140.

Aragón, Jorge. 2016b. "Introducción." In Participación, Competencia, y Representación Política: Contribuciones para el Debate, edited by Jorge Aragón. Lima: Jurado Nacional de Elecciones, 17-24. 
Arce, Moises. 2014. Resource Extraction and Protest in Peru. Pittsburgh: University of Pittsburgh Press.

Arellano-Yanguas, Javier. 2011. ¿Minería sin fronteras? Conflicto y desarrollo en regiones mineras del Perú. Lima: Instituto de Estudios Peruanos.

Asamblea Nacional de Gobiernos Regionales [ANGR]. 2014. Los Gobiernos Regionales al inicio de su segunda década: 46 experiencias de éxito de la gestion pública regional. Lima: Asemblea Nacional de Gobiernos Regionales.

Asociación Civil Transparencia. 2016. “Perfil del Congreso de la República 2016-2021.” Lima: Asociación Civil Transparencia.

Baca, Epifanio. 2016. “El presupuesto público 2017 es más de lo mismo: centralista, discrecional y clientelista." Nota de información y análisis 13. Lima: Grupo Propuesta Ciudadana.

Barrenechea, Rodrigo and Paolo Sosa Villagarcia. 2014. “Perú 2013: la paradoja de la estabilidad." Revista de Ciencia Política 34(1): 267-292.

Benavides, Martin, Juan León, Lucía Espezúa and Alejandro Wangeman. 2016. “Estudio especializado sobre población afroperuana." Retrieved on 5 February 2017 from www. grade.org.pe/wp-content/uploads/LIBRO_EEPA_mincugrade.pdf

Bland, Gary and Luis Chirinos. 2014. "Democratization Through Contention? Regional and Local Governance Conflict in Peru." Latin American Politics and Society 56(1): 73-97.

Bowen, Sally. 2000. The Fujimori File: Peru and Its President 1990-2000: The Peru Monitor.

Burt, Jo-Marie. 2007. Political Violence and the Authoritarian State in Peru: Silencing Civil Society. New York: Palgrave MacMillan.

Cameron, Maxwell A. and Eric Hershberg (eds.). 2010. Latin America's Left Turns. Politics, Policies, and Trajectories of Change. Boulder: Lynne Rienner Press.

Capital Humano y Social Alternativo. 2016. "IV Informe Alternativo. Balance de la sociedad civil sobre la situación de la trata de personas en el Perú, 2015-2016." Retrieved on 17 February 2017 from http://www.chsalternativo.org/balances-e-informes-alternativos?limit $=10$

Carrión, Julio, Patricia Zárate and Elizabeth Zechmeister (eds.). 2015. Cultura política de la democracia en Perú y en las Américas, 2014: gobernabilidad democrática a través de 10 años del Barómetro de las Américas. Lima: Instituto de Estudios Peruanos.

Casteñeda, Jorge. 2006. “Latin America's Left Turn.” Foreign Affairs 85(3): 28-44

Centro de Culturas Indígenas del Perú. 2016. Los pueblos indígenas frente a las elecciones generales 2016 en el Perú: informe de investigación. Lima: Centro de Culturas Indígenas del Perú.

Conaghan, Catherine. 2005. Fujimori's Peru: Deception in the Public Sphere. Pittsburgh: University of Pittsburgh Press.

Congreso de la República. n.d. "Reseña de leyes promulgadas." Parlamento Virtual Peruano. Retrieved from http://www4.congreso.gob.pe/pvp/leyes/index.asp.

Controlaría General de la República. 2014. Estudio de proceso de descentralización en el Perú. Lima: Controlaría General de la República.

Dargent, Eduardo and Paula Muñoz. 2016. "Peru: A Close Win for Continuity." Journal of Democracy 27(4): 145-158.

de la Torre, Augusto, Federico Filippini and Alain Ize. 2016. The Commodity Cycle in Latin America: Mirages and Dilemmas. LAC Semiannual Report, April 2016. Washington: World Bank.

Diamond, Larry and Leonard Morlino, eds. 2005. Assessing the Quality of Democracy. Baltimore: The Johns Hopkins University Press.

Dominguez, Francisco, Geraldine A. Lievesley, and Steve Ludlam. 2011. Right-wing Politics in the New Latin America: Reaction and Revolt. New York: Zed Books.

Espinosa De Rivero, Óscar. 2012. Las comunidades campesinas y la cuota indígena. Chapter in El sistema de la cuota electoral indígena en la Amazonía: Problemas y limitaciones. Lima: IDEA International.

Freedom House. Various Years. "Freedom in the World." Retrieved from https://freedomhouse.org/report-types/freedom-world 
Gender Equality Observatory of Latin America and the Caribbean. n.d. "Femicide or feminicide." Retrieved from http://oig.cepal.org/en/indicators/femicide-or-feminicide

Grompone, Romeo. 2016. "Lo que queda del día: Sobre partidos y sombras." En Participación, competencia, y representación política: contribuciones para el debate, edited by Jorge Aragón. Lima: Jurado Nacional de Elecciones, 113-131.

Guerra García, Gustavo. 2015. “Innovación en los sistemas de inversión pública: los casos de Perú y Corea y las lecciones aprendidas." Monograph.

INEI. 2008. "II Censo de comunidades indígenas de la Amazonía Peruana: resultados definitivos". Instituto Nacional de Estadística e Informática. Retrieved from http:/ / proyectos.inei.gob.pe/web/biblioineipub/bancopub/Est/Lib0860/index.htm

International IDEA. 2016. "The Quality of Democracies in Latin America." Retrieved on 24 February 2017 from http:/ / www.idea.int/publications/sod-in-latin-america/loader. cfm?csModule=security / getfile\&pageID=79379

IPSOS. 2016a. “Opinión Data." Año 16, Número 214. Accessed February 3, 2017 from http:// www.ipsos.pe/opinion_publica

IPSOS. 2016b. “Opinión Data." Año 16, Número 209. Accessed February 3, 2017 from http:/ / www.ipsos.pe/opinion_publica

IPSOS. 2016c. "Opinión Data." Año 16, Número 207. Accessed February 3, 2017 from http:// www.ipsos.pe/opinion_publica

IPU. n.d. "PARLINE database on national parliaments." Inter-Parliamentary Union. Retrieved from http:/ / www.ipu.org/parline-e/parlinesearch.asp

Jaime, Martín. 2016. Pobreza, heteronormatividad y discriminación: exclusión de personas TLGBI en las políticas públicas de salud en la región andina. Lima: Pontificia Universidad Católica del Perú.

Jaskoski, Maiah. 2014. "Environmental Licensing and Conflict in Peru's Mining Sector: A Path-Dependent Analysis." World Development 64(December): 873-883.

Kanashiro Fonken, Gustavo. 2016, 20 September. "Denuncias de intento de feminicidio suben $125 \%$ tras \#NiUnaMenos." El Comercio. Retrieved on 24 February 2017 from http:/ / elcomercio.pe/sociedad/lima/niunamenos-denuncias-violencia-genero-se-dispararon-noticia-1932265

Kenney, Charles. 2004. Fujimori's Coup and the Breakdown of Democracy in Latin America. Notre Dame: University of Notre Dame Press.

Latinobarómetro. 2016. "Informe Latinobarómetro 2016: El declive de la democracia." Retrieved on 3 February 2017 from http:/ / www.latinobarometro.org/latNewsShow.jsp

Levitsky, Steven 2013. "Peru: The Challenges of a Democracy without Parties." In Constructing Democratic Governance in Latin America, edited by Jorge I. Domínguez and Michael Shifter. Baltimore: Johns Hopkins University Press, 300-301.

Levitsky, Steven and Maxwell A. Cameron. 2003. “Democracy Without Parties? Political Parties and Regime Change in Fujimori's Peru." Latin American Politics and Society 45(Fall): $1-33$.

Levitsky, Steven and Kenneth Roberts. 2011. The Resurgence of the Latin American Left. Baltimore: Johns Hopkins University Press

Loayza, Jorge. 2016, 19 October. “Eduardo Ballón: 'se pueden producir nuevos conflictos sociales.'” La República. Retrieved on 5 February 2017 from http:/ /larepublica.pe/impresa/politica/813291-se-pueden-producir-nuevos-conflictos-sociales

López Ricci, José. 2014. “Presupuesto Participativo 11 años después: ¿Cambio de rumbo o más de lo mismo?" Cuadernos Descentralistas 30. Grupo Propuesta Ciudadana. Lima, Peru.

Luna, Juan Pablo and Cristóbal Rovira Kaltwasser. 2014. The Resilience of the Latin American Right. Baltimore: Johns Hopkins University Press.

McClintock, Cynthia. 1993. "Peru's Fujimori: A Caudillo Derails Democracy." Current History 92(March): 112-119.

McNulty, Stephanie. 2011. Voice and Vote: Decentralization and Participation in Post-Fujimori Peru. Stanford: Stanford University Press. 
Ministerio de la Mujer y Poblaciones Vulnerables [MIMP]. 2016. "Perú: personas víctimas de tentativa de feminicidio, según región, ene-jun 2016". Retrieved from http:// www.mimp.gob.pe/omep/imagenes/pers-victimas-tentativa-feminicidio-region-junio2016.jpg.

Muñoz, Paula. 2014. Gobernabilidad y desarrollo subnacional: problemas de coordinación interinstitucional. Lima: Universidad del Pacífico.

Muñoz, Paula and Yamilé Guibert. 2016. "Perú: el fin del optimismo." Revista de Ciencia Política 36(1): 313-338.

Orbegozo, Fernando. 2016, 30 December. "El complejo debate sobre el género en el Perú." El Comercio. Retrieved on 5 February 2017 from http://elcomercio.pe/sociedad/peru/ complejo-debate-sobre-genero-peru-informe-noticia-1957110

Participa Perú. 2005. "Propuesta general 2005: una propuesta sin ánimo descentralista." Retrieved on 7 March from http://www.propuestaciudadana.org.pe/sites/default/ files/publicaciones/archivos/presupuesto_2.pdf

Prodescentralización. 2011. Proceso de descentralización: balance y agenda a julio de 2011. Lima: Programa ProDescentralización.

Prodescentralización. 2015. Informe anual sobre el estado del proceso de descentralización 2014. Lima: Programa ProDescentralización.

Puig, Maria Luisa. 2016, 22 April. "Back to the Future with Fujimori?" Foreign Affairs. Retrieved on 14 February 2017 from https://www.foreignaffairs.com/articles/peru/2016-0422/back-future-fujimori.

Sanborn, Cynthia, Verónica Hurtado, and Tania Ramírez. 2016. La consulta previa en Perú: Avances y retos. Documento de Investigación 6. Lima: Universidad de Pacífico.

Sanborn, Cynthia and Alvaro Paredes. 2014. "Consulta previa: Perú." Americas Quarterly Special Report. Retrieved on 15 February 2017 from http://www.as-coa.org/sites/ default/files/ConsultaPreviaPeru.pdf

Sharkey, Laura. 2016, 30 March. "Peru's Path." Foreign Affairs. (March 30). Retrieved on 14 February from https:/ / www.foreignaffairs.com/articles/peru/2016-03-30/perus-path.

Tanaka, Martín. 2005. Democracia sin partidos: Perú, 2000-2005: los problemas de representación y las propuestas de reforma política. Lima: Instituto de Estudio Peruanos.

The Walk Free Foundation. 2016. Global Slavery Survey 2016. Retrieved from https:/ /www. globalslaveryindex.org/about/

Transparency International. 2017. “Corruption Perceptions Index 2016." Retrieved from https://www.transparency.org/news/feature/corruption_perceptions_index _2016\#table

World Bank. Various Years. "World Bank Open Data." Retrieved from https://data.worldbank.org/

Zas Friz Burga, Johnny. 2004. La insistencia de la voluntad: El actual proceso Peruano de descentralización política y sus antecedentes inmediatos (1980-2004). Lima: Defensoría del Pueblo.

Zechmeister, Elizabeth. 2014. "The Political Culture of Democracy in the Americas 2014." Latin American Public Opinion Project. Retrieved on 1 February 2017 from http:// www.vanderbilt.edu/lapop/ab2014/AB2014_Comparative_Report_English_V3_revised_011315_W.pdf

Stephanie McNulty is an Associate Professor at Franklin and Marshall College and Latin Americanist with expertise in decentralization, participatory governance, gender, and development. She has been researching and writing about Peruvian democracy for two decades. In addition to many refereed journal articles, she is the author of Voice and Vote: Decentralization and Participation in Post-Fujimori Peru (Stanford University Press, 2011). Email: smcnulty@fandm.edu 
- 